\title{
A modular perfused chamber for low- and normal- temperature microscopy of living cells
}

\author{
Valeria Sigot ${ }^{1}$, José Manuel Pellegrino ${ }^{2}$, Edgardo Elvio Guibert ${ }^{1}$, and Joaquín Valentín Rodriguez ${ }^{1}$ \\ ${ }^{1}$ Centro Binacional (Argentina-Italia) de Investigaciones en Criobiologia Clinica y Aplicada (CAIC), Universidad \\ Nacional de Rosario, Rosario, Argentina and ${ }^{2}$ Instituto de Fisiología Experimental (IFISE). Dpto. Cs. Fisiológicas, \\ Facultad de Ciencias Bioquimicas y Farmacéuticas, Universidad Nacional de Rosario, Rosario, Argentina
}

BioTechniques 50:251-254 (April 2011) doi 10.2144/000113653

Keywords: perfused chamber; low- and normal-temperature microscopy; hypothermic cell preservation; quantum dots

Supplementary material for this article is available at www.BioTechniques.com/article/113653.

An inexpensive modular perfused chamber (MPC) designed for low- and normal-temperature live-cell imaging is presented. The device consists of four lathed pieces of stainless steel assembled as a cylindrical open chamber that can hold either round or square glass coverslips. The chamber is connected to a thermal-bath operating with recirculation. For image acquisition at $4^{\circ} \mathrm{C}$, cooled air is blown toward the coverslip surface to prevent condensation. Principal advantages of this device are thermal stability in the sample environment, rapid response to changes in temperature set point, and easy sample insertion. The device enables the study of dynamic processes in cells governed by large temperature differences such as those imposed by hypothermic preservation of cells $\left(0-4^{\circ} \mathrm{C}\right)$ followed by rewarming to normothermia $\left(37^{\circ} \mathrm{C}\right)$. The capabilities of the MPC were demonstrated by monitoring the internalization of fluorescent quantum dots (QDs) in rat hepatocytes after hypothermic storage and during rewarming with an inverted microscope.

Cold storage of mammalian cells in preservation solutions is a well-known method to protect cells against degradative processes, and is widely used in experimental (1) and clinical applications (2). A detrimental aspect of cooling a cell to a temperature lower than normothermic is the lipid phase transition which directly affects the membrane integrity. The damage is cumulative, time-dependent, and it is expressed upon returning to normothermia (3). Therefore, temperature-controlled live cell imaging performed at the end of cold storage and during rewarming will allow monitoring of the onset of preservation injury. In spite of the existence of a variety of custommade devices for temperature controlled microscopy (4-7), there are limited options for working with live specimens below $10^{\circ} \mathrm{C}$ $(6,7)$. This work deals with the construction and performance of an inexpensive modular perfused chamber (MPC) adapted to the stage of an inverted microscope for imaging live cells at temperatures from $\operatorname{low}\left(4^{\circ} \mathrm{C}\right)$ to normal $\left(37^{\circ} \mathrm{C}\right)$. The MPC consists of four lathed pieces of stainless steel assembled as an open cylinder that can hold round or square glass coverslips. The device is connected to a standard thermal bath with water recirculation. For image acquisitions below $10^{\circ} \mathrm{C}$, cooled air is blown on to the coverslip surface to prevent condensation. The price for this chamber, comprising the materials and the cost for lathing work, is estimated to be 100 USD. The chamber performance was tested for thermal equilibration and stability at $4^{\circ} \mathrm{C}$ and at $37^{\circ} \mathrm{C}$, and its application in live cell experiments was assessed by the use of quantum dots (QDs), highly fluorescent nanoparticles suitable for long-term imaging (8). QDs conjugated with ligands have enabled the recognition of multiple targets and elucidation of cellular dynamic processes. Biotinylated epidermal growth factor (EGF) ligand conjugated to streptavidin-coated QDs (QD-EGF) binds to its surface receptor in target cells, leading to activation and endocytosis (9). Receptor-mediated uptake of EGF-QDs complexes into cold-stored rat hepatocytes was evaluated after rewarming to $37^{\circ} \mathrm{C}$ in order to test the capability of the MPC.

\section{Materials and methods}

Components

As shown in Figure 1, the thermostated system comprises the MPC itself, placed in a standard $35-\mathrm{mm}$ stage (Figure $1 \mathrm{~A}$ ), two lateral luer ports and tubing for the connection of the MPC to a thermal bath circulator. An aquarium air pump, connected to a bubbler submerged in the coolant, blows a stream of cool air under the glass coverslip to prevent condensation (Figure 1B). The air is blown through a polytetrafluoroethylene (PTFE) tube (o.d. $3 \mathrm{~mm}$; i.d. $2 \mathrm{~mm}$ ) placed at a distance of $\leq 10 \mathrm{~mm}$ from the objective lens, avoiding direct contact with the coverslip (Figure 1C). Imaging was performed in a Nikon C1 plus confocal microscope mounted on Eclipse TE-2000-E2 inverted microscope (Figure 1D) equipped with a $40 \times$ Plan Apo-Chromat dry objective (N.A. = 0.95; Nikon, Melville, NY, USA).

Thermal bath circulator and supplements The thermal bath (Figure 1D) (Model no. 521/D; Novaética, São Paulo, Brazil) is equipped with a temperature range of $0-100^{\circ} \mathrm{C}$, accuracy of temperature control $\pm 0.1^{\circ} \mathrm{C}$, and fluid capacity of 8 $\mathrm{L}$ at a flow rate of $0.4 \mathrm{~L} / \mathrm{min}$. The recirculating solution is a 1:1 mixture of ethylene glycol and water suitable for working at nonfreezing subzero temperatures. Two 

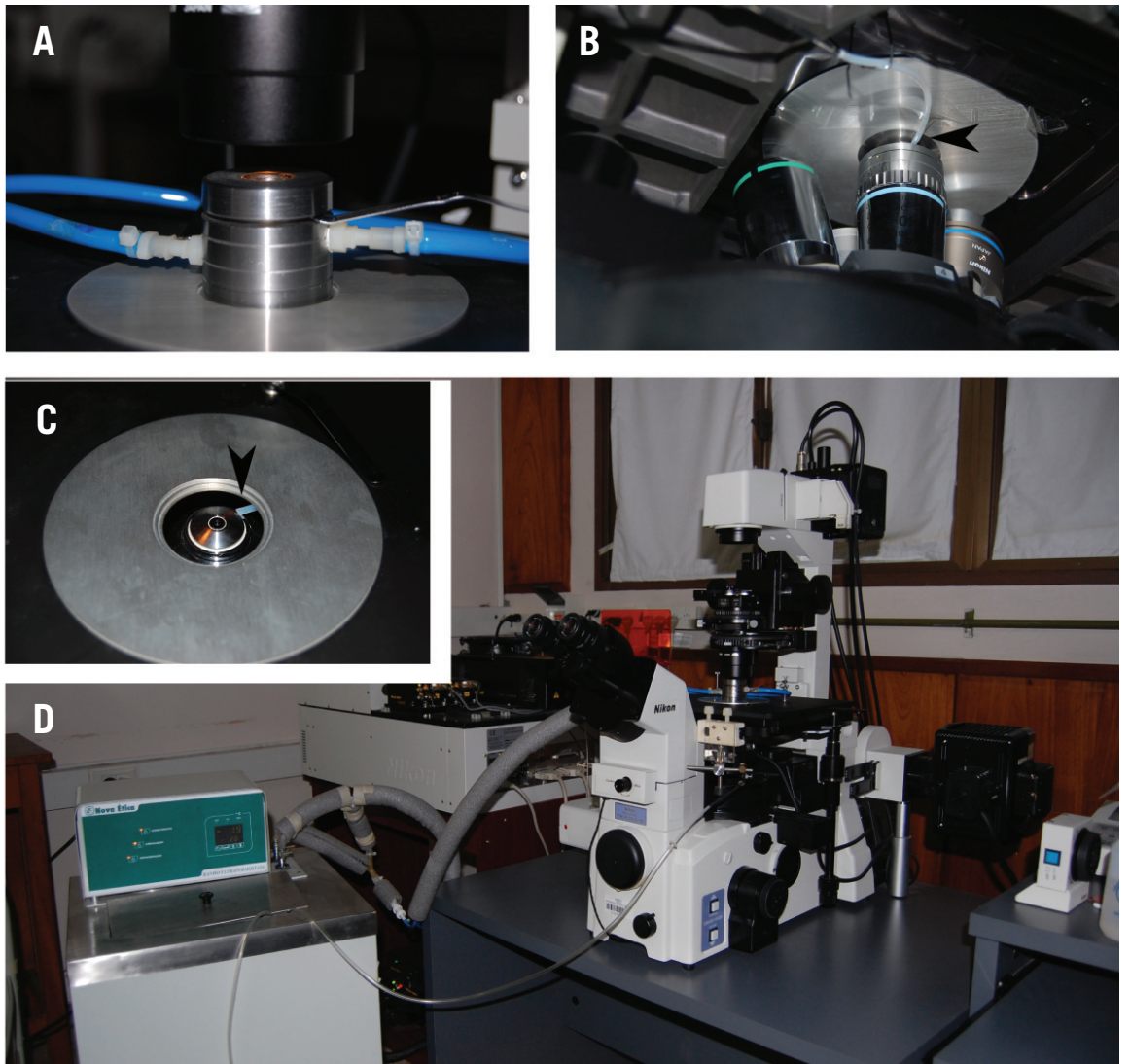

Figure 1. Installation of the MPC on the microscope stage. (A) MPC mounted in a 35-mm stage, with inlet and outlet ports and tubing connecting the chamber to the thermal bath. (B) Bottom view of the air-blowing PTFE tube (black arrow); (C) Top view of the PTFE tip (black arrow) placed $10 \mathrm{~mm}$ apart from the lens of a $40 x$ dry objective. (D) Broad view of thermal bath and inverted microscope.
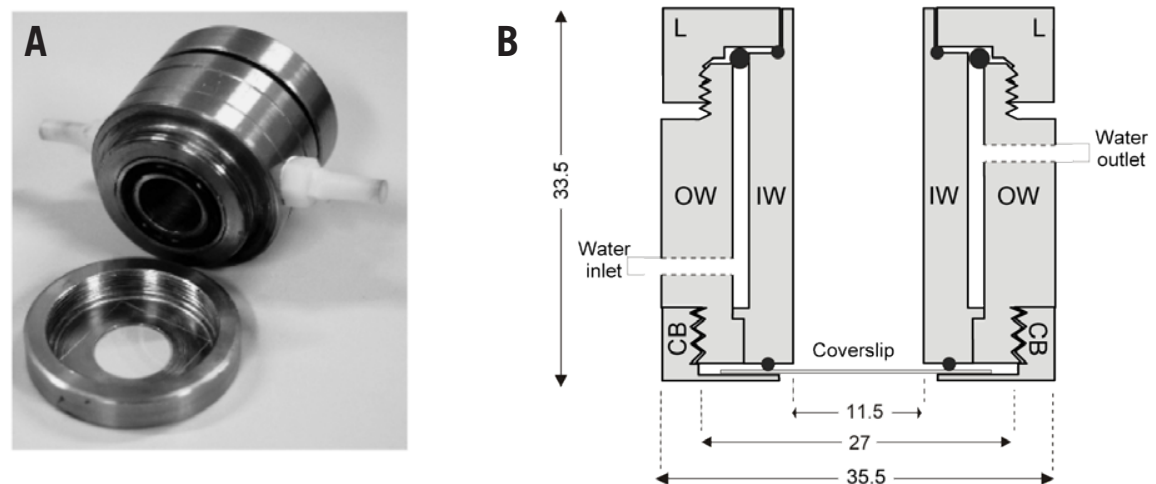

Figure 2. MPC design and dimensions. (A) Photograph of the open chamber and coverslip insertion; (B) Vertical cross-section of the MPC. The overall dimension is $33.5 \mathrm{~mm}$ height $\times 35.5 \mathrm{~mm}$ o.d. and uses square or round glass coverslips up to $25 \mathrm{~mm}$ in size. L, lid; OW, outer wall; IW, inner wall; CB, chamber base. O-rings are shown as black circles. All dimensions are expressed in millimeters.

male luer fittings $(1 / 4-28$ thread pK10 white nylon; Small Part Inc., Logansport, IN, USA) are plugged into the MPC connecting the chamber to the recirculating thermal bath through two polyamide tubes (i.d. $4.0 \mathrm{~mm}$; o.d. $6.0 \mathrm{~mm}$ ). The volume of cooling solution (1:1 ratio of ethylene glycol:water) contained in the chamber is $3 \mathrm{~mL}$. Undesired environmental heat transfer to the circulating solution during imaging at low tempera- tures $\left(<10^{\circ} \mathrm{C}\right)$ is reduced by coating the polyamide tubes with polyethylene foam as insulating material. Additional instrumentation includes thermocouples and thermometer (TES-1307 Datalogging K/J Thermometer; TES Electrical Electronic Corp., Taipei, Taiwan), O-rings of Buna-N polymer (cross-section width of $1.78 \pm 0.08 \mathrm{~mm}$ and $2.5 \pm 0.08 \mathrm{~mm}$; MAG S.R.L., Rosario, Argentina) and an aquarium air pump with $1200 \mathrm{~mL} / \mathrm{min}$ flow (Excel 2, Avant, Avant Sales, Mississauga, Ontario, Canada, or similar).

\section{MPC design and assembling}

The scheme and dimensions of the MPC are provided in Figure 2. It is built of four lathed pieces of surgical steel assembled as a cylinder of $33.5 \mathrm{~mm}$ height with an o.d. of $35.5 \mathrm{~mm}$ (See detailed dimensions in Supplementary Figure S1). The main body of the chamber is composed of an internal open cylinder, labeled inner wall (IW), and an external cylinder, and labeled outer wall (OW). Two annular pieces are screwed to the main body and the chamber is sealed with O-rings; the piece on top is the chamber lid (L) and the bottom piece forms the chamber base (CB). The IW is grooved to accommodate an O-ring (cross section width of $1.78 \pm 0.08 \mathrm{~mm}$ ) which seals the coverslip. The complete chamber is first assembled without the coverslip and connected to the thermal bath for equilibration at the desired temperature. Next, the $\mathrm{CB}$ is unscrewed open, and the coverslip is placed inside. Then, the CB is placed back, sealing the chamber.

\section{Sample insertion into the MPC}

Prior to use with cells, each part of the MPC is sonicated with detergent, rinsed with distilled water and cleaned with ethanol or, if required, autoclaved $\left(15 \mathrm{~min}\right.$ at $\left.121^{\circ} \mathrm{C}\right)$. The O-ring sealing the coverslip is discarded after each experiment. Cells cultured in multiple glass coverslips can be inserted once the MPC has been equilibrated at the desired temperature, and immediately before imaging. A minimum of $500 \mu \mathrm{L}$ buffer, media, or reagents is added to cells from the top lid before placing the MPC in the microscope stage. Alternatively, cells can be grown inside the MPC and later connected to the thermal bath. Once imaging acquisition starts, subsequent buffer changes can be accomplished using a pipet or syringe without moving the chamber from the stage by simply lifting the condenser above. Coverslips can be removed from the original medium and inserted in the MPC in $<1 \mathrm{~min}$.

\section{Thermal response test}

Temperature in the thermal bath and inside the MPC was simultaneously recorded using two thermocouple probes connected to an electronic thermometer. One probe was inserted in the ethylene glycol-water solution in the thermal bath. The second one was transiently glued to the inner wall of the chamber keeping the probe in contact with the solution and coverslip surface. After setting the bath at $4^{\circ} \mathrm{C}$ or $37^{\circ} \mathrm{C}$, the chamber was connected to the bath and the ethylene glycol-water recirculation started. 
A

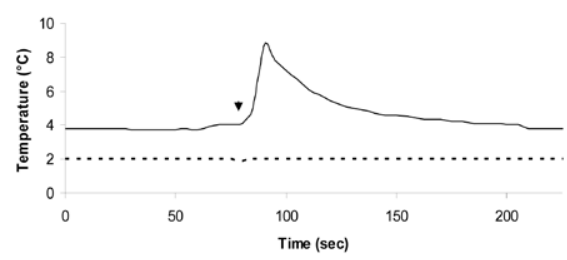

B

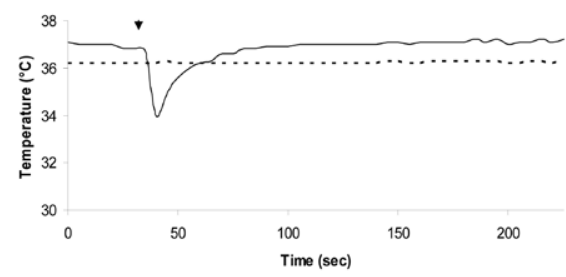

Figure 3. Thermal response of the MPC after replacement of $500 \mu \mathrm{L}$ water. (A) $4^{\circ} \mathrm{C}$. (B) $37^{\circ} \mathrm{C}$. Temperature was recorded every $5 \mathrm{~s}$. Temperature was measured in the MPC (solid line), as well as the thermal bath (dashed line). The arrows show the time point at which room-temperature water was added.
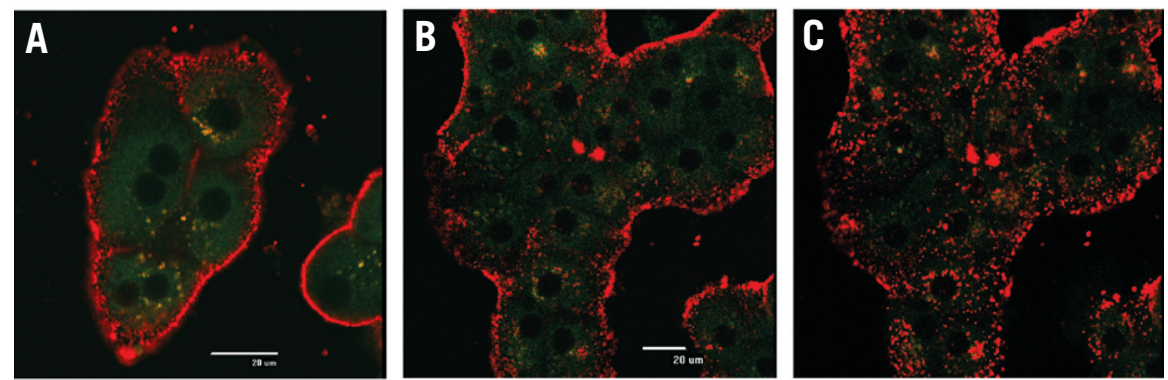

Figure 4. Time course of EGF-QD internalization after cold storage. Cultured rat hepatocytes preincubated with EGF-QD ${ }_{655}$ complexes and preserved in UW solution were imaged in the MPC by confocal microscopy. (A) $4^{\circ} \mathrm{C}$ in UW; (B) $37^{\circ} \mathrm{C}, 5$ min after replacing UW with Tyrode's buffer; (C) at $37^{\circ} \mathrm{C}, 35$ min after replacing UW solution by Tyrode's buffer. Five independent cell cultures followed by hypothermic preservation were carried out. Scale bar, $20 \mu \mathrm{m}$.

Then, $500 \mu \mathrm{L}$ water was added to the MPC and temperature was allowed to stabilize. Water was replaced by an equal volume of room temperature water and data was recorded every $5 \mathrm{~s}$. At $4^{\circ} \mathrm{C}$, data recording was performed while flushing a continuous stream of cool air under the coverslip. Data was downloaded using the Thermo-link software compatible with the TES-1307 Datalogging K/J Thermometer.

Reagents for cell culture, preservation, and labeling

All reagents were of analytical grade. Williams' E medium (MP Biomedicals, Cleveland, OH, USA) was supplemented with 5\% FBS, plus $1 \mathrm{~g} / \mathrm{L} \mathrm{BSA}, 2.2 \mathrm{~g} / \mathrm{L}$ $\mathrm{NaHCO}_{3}, 5 \mathrm{mg} / \mathrm{L}$ insulin, $133 \mathrm{IU} / \mathrm{L}$ penicillin, $0.1 \mathrm{mg} / \mathrm{L}$ streptomycin, and $50 \mu \mathrm{M}$ prednisolone 21-hemisuccinate (MP Biomedicals).

The composition of modified University of Wisconsin (UW) solution (10) was $100 \mathrm{mM}$ lactobionic acid, $25 \mathrm{mM} \mathrm{K}_{2} \mathrm{HPO}_{4}$, $5 \mathrm{mM} \mathrm{MgSO}_{4}, 30 \mathrm{mM}$ raffinose, $2.5 \mathrm{mM}$ adenosine, $3 \mathrm{mM}$ reduced glutathione GSH, $1 \mathrm{mM}$ allopurinol, $5 \%$ polyethylene glycol $(\mathrm{MW}=8000), 15 \mathrm{mM}$ glycine, $0.25 \mathrm{mg} / \mathrm{mL}$ streptomycin, and $10 \mathrm{IU} / \mathrm{mL}$ penicillin $\mathrm{G}$, pH 7.40, $380 \mathrm{mOsm} / \mathrm{Kg}$, saturated with $\mathrm{N}_{2}$.

Tyrode's buffer (plus) comprises $135 \mathrm{mM}$ $\mathrm{NaCl}, 10 \mathrm{mM} \mathrm{KCl}, 0.4 \mathrm{mM} \mathrm{MgCl}_{2}, 1 \mathrm{mM}$
$\mathrm{CaCl}_{2}, 10 \mathrm{mM}$ HEPES, $20 \mathrm{mM}$ glucose, and $0.1 \%$ BSA, pH 7.20.

Bioconjugation of QDs

Biotin-EGF (Molecular Probes, Invitrogen, Carlsbad, CA, USA) was conjugated to Streptavidin-QD (StAv-QDs) (Invitrogen) emitting at $655 \mathrm{~nm}$ at a ratio of $4: 1$, respectively, and referred to as EGF-QDs complexes. Biotin-EGF was incubated with $\mathrm{StAv}-\mathrm{QD}_{655}$ for $30 \mathrm{~min}$ at room temperature in $\mathrm{PBS} / 0.2 \% \mathrm{BSA}$ at a final concentration of $20 \mathrm{nM}$ QDs. For live-cell labeling and imaging, complexes were diluted in Tyrode's buffer to a final concentration of $2 \mathrm{nM}$ QDs.

Isolation and primary culture of rat hepatocytes

Hepatocytes were isolated from Wistar rats $(250-300 \mathrm{~g})$ by collagenase perfusion using the procedure originally described by Seglen (11) and modified by us (12). Cell viability of freshly isolated cells was tested by the exclusion of $0.2 \%$ trypan blue dye (TBE assay) dissolved in PBS. Preparations with a TBE $>85 \%$ were considered suitable for cell culture. Hepatocytes were seeded at a density of $7 \times 10^{5}$ cells $/ \mathrm{cm}^{2}$ in collagencoated culture plates with glass coverslips and incubated in Williams' E medium for $24 \mathrm{~h}$ in a gas-controlled incubator $\left(5 \% \mathrm{CO}_{2}, 37^{\circ} \mathrm{C}\right)$ before the hypothermic preservation step.
Hypothermic preservation of cultured hepatocytes in UW solution

After 24 h, glass coverslips with cultured hepatocytes were washed twice with PBS and preserved for $24 \mathrm{~h}$ at $4^{\circ} \mathrm{C}$ in $1 \mathrm{~mL}$ UW solution supplemented with $2.5 \mathrm{mM}$ adenosine and $3 \mathrm{mM}$ glutathione previously bubbled with $\mathrm{N}_{2}$. After preservation, UW was removed and hepatocytes rinsed and imaged in Tyrode's buffer.

\section{Incubation with EGF-QD complexes} and live cell microscopy

Coverslips with cultured hepatocytes were incubated with the EGF-QDs ( $2 \mathrm{nM}$ $\left.\mathrm{QD}_{655}\right)$ in $1 \mathrm{~mL}$ UW solution and coldstored for $24 \mathrm{~h}$ at $4^{\circ} \mathrm{C}$. After hypothermic preservation, the coverslip was inserted in the MPC pre-equilibrated at $4^{\circ} \mathrm{C}$. Hepatocytes were then imaged in UW solution at $4^{\circ} \mathrm{C}$ by confocal microscopy. After $5 \mathrm{~min}$, UW solution was replaced by $500 \mu \mathrm{L}$ pre-chilled Tyrode's buffer and the temperature in the MPC increased to $37^{\circ} \mathrm{C}$. QDs were immediately monitored every $5 \mathrm{~min}$ for $40 \mathrm{~min}$ during and after rewarming to $37^{\circ} \mathrm{C}$. QD $\mathrm{Q}_{65}$ was excited with laser line $488 \mathrm{~nm}$, and detected with a long-pass filter LP650. Hepatocytes autofluorescence was visualized upon excitation at $488 \mathrm{~nm}$ and detected with a $515 / 30 \mathrm{~nm}$ bandpass filter. Images were analyzed with the EZ-C1 software provided with the microscope.

\section{Results and discussion}

\section{Thermal response}

The MPC is designed to hold a volume of $0.5-1 \mathrm{~mL}$ medium or buffer. Addition of reagents or buffer replacement requires the system's fast response to maintain the temperature in the MPC during live-cell imaging. Figure 3 shows the thermal response over time, after replacing $500 \mu \mathrm{L}$ of water pre-equilibrated at $4^{\circ} \mathrm{C}$ (Figure $3 \mathrm{~A}$ ) and pre-equilibrated at $37^{\circ} \mathrm{C}$ (Figure $3 \mathrm{~B}$ ) in the MPC, by an equal volume of water at room temperature $\left(20-22^{\circ} \mathrm{C}\right)$. Temperature was recorded every $5 \mathrm{~s}$ and at $4^{\circ} \mathrm{C}$ a continuous stream of cool air was flushed underneath the coverslip. Complete equilibration to $4^{\circ} \mathrm{C}$ was achieved after $2 \mathrm{~min}$, whereas at $37^{\circ} \mathrm{C}$, the equilibration was reached after $30 \mathrm{~s}$.

\section{Live-cell microscopy of}

EGF-QD uptake after hypothermic preservation of hepatocytes

Many biological reactions have been studied at different temperatures in order to find optimal conditions to promote or block cellular processes. During cell and tissue hypothermic preservation at $4^{\circ} \mathrm{C}$, metabolism is diminished and energy-dependent 
processes such as endocytosis are arrested. Activation of the EGF receptor results in clathrin-mediated endocytosis via coated pits, covalent modification of the receptor, and endosomal trafficking followed by down-regulation through proteosomal degradation and recycling to the cell membrane (13). It is of particular interest to monitor the receptor-mediated uptake of nanoparticles after hypothermic storage, since the ability to reassume endocytosis will indicate a basal recovery in ATP pool (2), as well as the viability of cells. The designed MPC was employed to follow the uptake of EGF-QD complexes in rat hepatocytes after hypothermic preservation at $4^{\circ} \mathrm{C}$. Each coverslip with cells was inserted in the chamber pre-cooled at $4^{\circ} \mathrm{C}$. The chamber was filled with UW solution at $4^{\circ} \mathrm{C}$ and the system mounted in the microscope stage. Image acquisition at the end-point of preservation showed the characteristic polygonal shape of hepatocytes grown in monolayer and the QDs concentrated on the cell membrane (Figure 4A). Prior to the rewarming step, UW solution was replaced by Tyrode's and temperature in the MPC was set at $37^{\circ} \mathrm{C}$. Image acquisition continued during rewarming and extended for $40 \mathrm{~min}$. After $5 \mathrm{~min}$ at $37^{\circ} \mathrm{C}$, QDs were still concentrated on the cell membrane (Figure 4B) and internalization was observed after $30 \mathrm{~min}$ (Figure $4 \mathrm{C}$ ) as a decrease in membrane labeling and the typical dot-pattern perinuclear distribution of the internalized QDs (14).

Condensation on the glass coverslip surface is a major technical obstacle that interferes with the focus adjustment of the microscopic field while imaging below $10^{\circ} \mathrm{C}$. This was prevented by blowing cool air in the vicinity of the coverslip.

The experiments herein demonstrate the applicability of the MPC to evaluate the effect of cold storage on the competence for endocytic and energy-dependent transport on primary culture of hepatocytes. The MPC becomes a valuable tool to monitor the onset of cold-induced injury in the specimen expressed during rewarming to $37^{\circ} \mathrm{C}$ and alternatively, to examine cellular processes occurring while cooling to the final preservation temperature. These observations may help in developing new strategies for drug delivery at low temperatures, as well as the incorporation of fluorescent biosensors of cold-induced injury. The application of ligand-tagged QDs enabled live-cell microscopy within the MPC for >30 min without detectable photobleaching. In summary, the designed MPC is a suitable device for live-cell microscopy at low to normal temperatures on an inverted microscope. The features of the chamber include (i) ease of assembly that enables insertion of each coverslip (round or square) into the pre-cooled/ pre-warmed chamber in $<1 \mathrm{~min}$; (ii) fast thermal response and stable operation for working with a dry objective; (iii) ability to autoclave, so cells can be grown directly in the chamber; (iv) O-ring sealing to prevent media leakage; and $(v)$ a fit with standard $35 \mathrm{~mm}$-diameter stage holders.

The device, with an estimated cost of 100 USD, is a versatile design that can be connected to any commercially available thermal bath and adapted to the stage of an inverted microscope.

\section{Acknowledgments}

We would like to thank Gaetano Pellegrino for machining the MPC and his ideas concerning its design. This work was supported by grant no. PIP-1208 from the Consejo Nacional de Investigaciones Científicas y Técnicas (CONICET), and Prot n. 19096/PT Regione Autonoma Friuli, Venezia Giulia, and Progetti Alta Rilevanza, Ministero degli Esteri, Italy, prot. 269/P-0114337. V.S., J.V.R., J.M.P., and E.E.G. are members of CONICET.

\section{Competing interests}

The authors declare no competing interests.

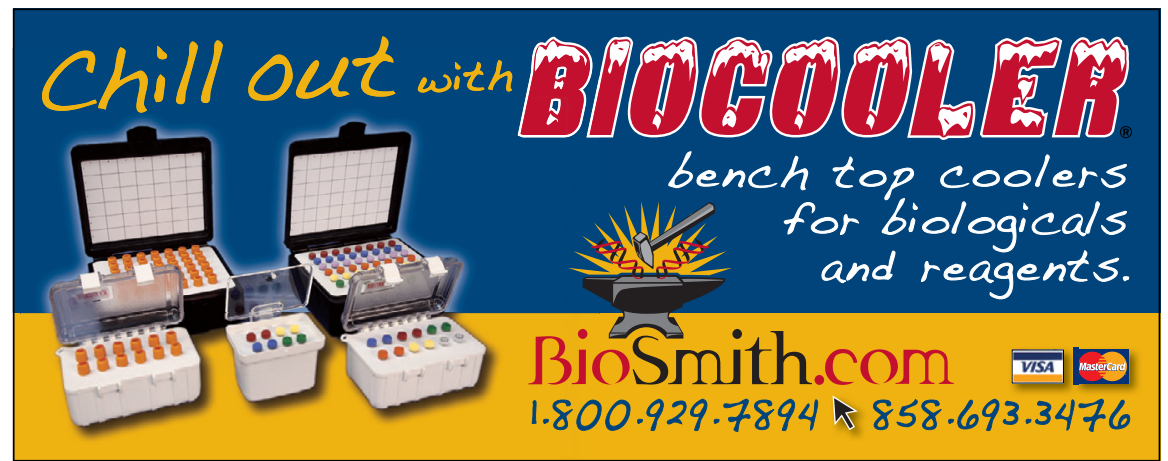

\section{References}

1.Sigot, V., M.G. Mediavilla, G. Furno, J.V. Rodriguez, and E.E. Guibert. 2004. A simple and effective method to improve intrasplenic rat hepatocyte transplantation. Cell Transplant. 13:775-781.

2.Fuller, B.J. 1987. Storage of cells and tissues at hypothermia for clinical use. Symp. Soc. Exp. Biol. 41:341-362.

3. Rubinsky, B. 2003. Principles of low temperature cell preservation. Heart Fail. Rev. 8:277 284.

4.Picard, C., V. Hearnden, M. Massignani, S. Achouri, G. Battaglia, S. MacNeil, and A. Donald. 2010. A microincubator for cell and tissue imaging. BioTechniques 48:135-138.

5. Heidemann, S.R., P. Lamoureux, K. Ngo, M. Reynolds, and R.E. Buxbaum. 2003. Open-dish incubator for live cell imaging with an inverted microscope. BioTechniques 35:708716.

6. Rabin, Y. and B. Podbilewicz. 2000. Temperature-controlled microscopy for imaging living cells: apparatus, thermal analysis and temperature dependency of embryonic elongation in Caenorhabditis elegans. J. Microsc. 199:214223.

7. Buchner, O., C. Lutz, and A. Holzinger. 2007. Design and construction of a new temperaturecontrolled chamber for light and confocal microscopy under monitored conditions: biological application for plant samples. J. Microsc. 225:183-191.

8. Alivisatos, A.P., W. Gu, and C. Larabell. 2005. Quantum dots as cellular probes. Annu. Rev. Biomed. Eng. 7:55-76.

9. Lidke, D.S., P. Nagy, T.M. Jovin, and D.J. Arndt-Jovin. 2007. Biotin-ligand complexes with streptavidin quantum dots for in vivo cell labeling of membrane receptors. Methods Mol. Biol. 374:69-79.

10. Rodriguez, J.V., M.E. Mamprin, M.G. Mediavilla, and E.E. Guibert. 1998. Glutathione movements during cold preservation of rat hepatocytes. Cryobiology 36:236-244.

11.Seglen, P.O. 1976. Preparation of isolated rat liver cells. Methods Cell Biol. 13:29-83.

12.Guibert, E.E., M.G. Mediavilla, M.E. Mamprin, and J.V. Rodriguez. 1998 Hypothermic storage of periportal and perivenous rat hepatocytes. Cell Transplant. 7:345-355.

13.Schlessinger, J. 2002. Ligand-induced, receptor-mediated dimerization and activation of EGF receptor. Cell 110:669-672.

14.Lidke, D.S., P. Nagy, R. Heintzmann, D.J. Arndt-Jovin, J.N. Post, H.E. Grecco, E.A. Jares-Erijman, and T.M. Jovin. 2004. Quantum dot ligands provide new insights into erbB/HER receptor-mediated signal transduction. Nat. Biotechnol. 22:198-203.

Received 16 December 2010; accepted 18 February 2011.

Address correspondence to Valeria Sigot, Centro Binacional (Argentina-Italia) de Investigaciones en Criobiología Clínica y Aplicada (CAIC), Universidad Nacional de Rosario. Arijón 28 bis, S2011BXN Rosario, Argentina. e-mail: vsigot@ fbioyf.unr.edu.ar

To purchase reprints of this article, contact: biotechniques@fosterprinting.com 